\title{
Asian Modernity: Cricket in Princely States - Case Example of Dhruve Pandove Cricket Stadium cum Gymkhana Club Patiala, Punjab
}

\author{
Parminder Kaur \\ Chitkara School of Planning \& Architecture, Chitkara University, Punjab. India
}

Email: parminder.kaur@chitkara.edu.in

\section{ARTICLE INFORMATION}

Received: February 22, 2017

Revised: April 27, 2017

Accepted: June 22, 2017

Published online: July 03, 2017

Keywords:

Modernization; Entertainment; Society; Maharajas; Cricket Club.

DOI: http://doi.org/10.15415/cs.2017.51003

\begin{abstract}
The paper bringing about the certain changes, which were implies in Asian countries during the 18th century, when most part of these countries comes under British impact. Considering India only, the changes were not focusing only on the architectural style, but it was the entire process to structure the society in a better way. Britishers, by nature were very fond of recreation, entertainment, luxury in their life. Sports was one of the medium of their entertainment through which they interact among high societies. When cricket was introduced in India by Britishers, it was become most popular game among all the states. Maharajas of princely states were always try to copy the British life style, so they adopted cricket also with full obsession. Maharajas of Patiala, princely state Punjab along with their royal families, were in passionate lead to support Cricket as major sport (Majumdar, B. 2008). They had taken cricket to utmost priority and formed their own cricket grounds in Chail and Patiala. Maharaja Rajinder Singh, constructed a cricket ground and pavilion in 1890 in Patiala named as 'Dhruve Pandove Stadium' from where he initiated the cricket patronage (Sarkar, A. 2016). The pavilion is constructed in colonial style, which has given India a number of leading crickets, is still intact in good and working condition.
\end{abstract}

\section{Modernization of Ancient India with the Advent of British Empire}

The modern world had its origin in Europe as a result of a process of cultural, economic and political change and this was extended, through the colonial expansion, to Asian countries. The modern impact on the Asian countries was mostly because of the western influence, not in terms that the Europeans brought civilizations to Asia but because of the European economic, political, and cultural impact caused the disruption of the traditional Asian countries and their societies (Borsa, G. 2000). Around the eighteen Century variety of significant events happened in the world. Out of all the events, one major event which significantly impacted the nation was the 'Industrial Revolution' which started in England. It step by step unfolds to other countries of European nation. It results to the finding of new trade routes including the road and sea routes. In 1498, Portuguese discovers the one such sea trade route to India called 'Vasco da Gama'. As a result, all the powerful nations started coming to India for trade. Beginning of modernization in Indian society starts with approaching of these European powers to India for trade. At the beginning, the European and the British traders came to India for commercial purpose only.
By 1600 , British establish 'East India Company' in India and create their strong political control. By this they were able to monopolies the trade within India. This accelerated the process of modernization (Ghouse, A. N. 1954).

\subsection{British Impact on Society and Culture}

There is no doubt British impacted the Indian societies in many ways. At the beginning of Industrial Revolution during $18^{\text {th }}$ century, there were various social practices prevailing in India like child marriage, female infanticide, sati, polygamy and rigid class systems. But with the advent of British in India, various revolutions took place with their new ideas such as liberty, equality, freedom and human rights. This brought huge changes in the Indian society. Several legal measures were taken to boost the power of women. Many of the beliefs were prohibited which were against the women growth in society. For example, in 1829 , sati practice was banned by the then Governor General. In 1856, Widow Remarriage act was passed. There were not any ban on inter-caste and intercommunal marriages after 1872. Child marriage was also banned after implementing Sharda Act in 1929. The act was also provided to restrict the marriage age. Now it was illegal to marry a girl below 14 and a boy below 18 years. New system 
of law and justices also introduced in India by Britishers. If anyone not obeying such laws, various civil and criminal courts were established. All these efforts impacted and reform the Indian societies, various religious organizations which results in leading towards the modernization. Cultural transformation was brought in India by conjointly Britishers and Europeans who stayed in our country. We should also appreciate that our modern life is shaped to a large extent by our immediate past. The British control over a large part of the country becomes an important deciding factor. Number of cultural and legal changes that transpire as a result of British rule continue to affect our life even these days. The modern facilities like transportation, the club life, the colonial buildings like the Rashtrapati Bhavan and the Parliament are evidence of the British rule in India (National Institute of Open Schooling, (2008) Module 1).

\section{Modernization in Entertainment}

With the advent of British period Modernization also took place in various aspects like recreation, entertainment, sports, culture, education etc. From the ancient periods sports and other recreational activities were always existed in all generations from time to time. (Fig. 1)(Fig. 2)

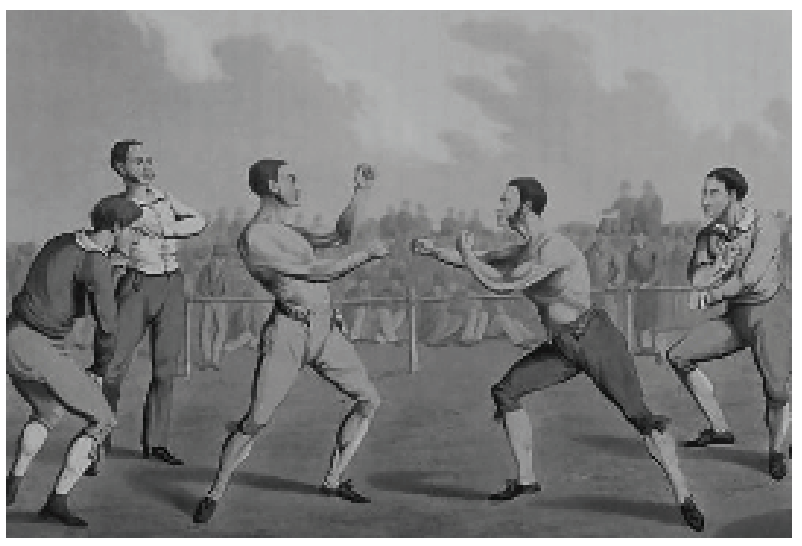

Figure 1. A variety of pre-industrial sports and pastimes (Boxing) (Source: (Source:https://www.pearsonschoolsandfecolleges.co.uk/ FEAndVocational/SportsStudies/ALevel/OCRALevelPE2008/ Samples/A2PEStudentBookSamplePages/PEforOCR(A2) SBCH01.pdf).

Before Industrial Revolution, the main source of entertainment in sports were boxing, race, horse race, etc. But the British Empire, takes the entertainment in new direction with modernization by adding the club life and modern sports activities (Popular recreation in pre- industrial Britain, P.9-11).

\subsection{Club life \& sports activities}

In the early days, the club was a basic affair serving as a "meeting place", with a few old books and some drinks.

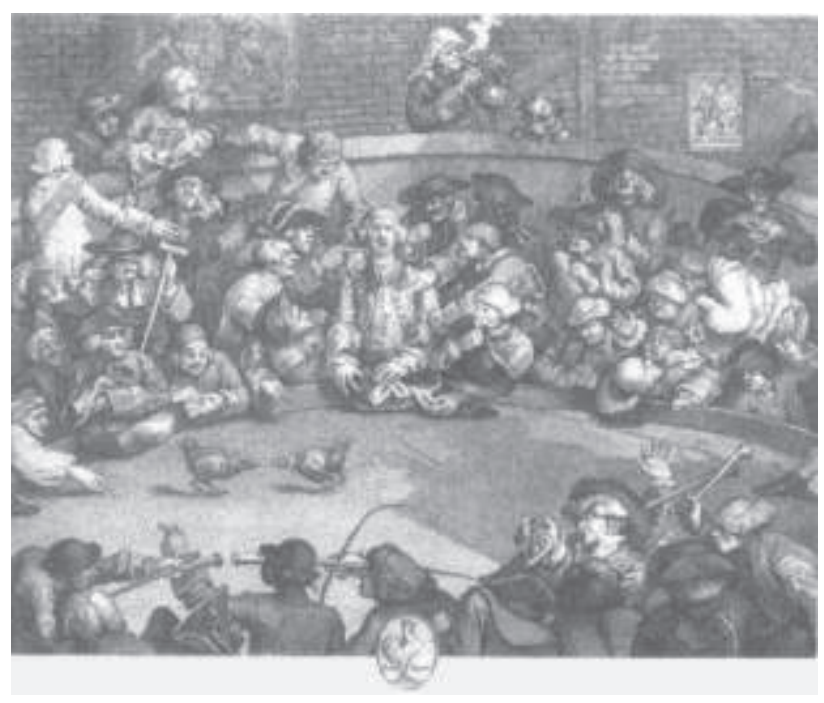

Figure 2. A variety of pre-industrial sports and pastimes (Birds fight) (Source: https://www.pearsonschoolsandfecolleges.co.uk/ FEAndVocational/SportsStudies/ALevel/OCRALevelPE2008/ Samples/A2PEStudentBookSamplePages/PEforOCR(A2) SBCH01. pdf).

Clubs in the large stations usually had badminton and squash courts and, often after the 1920s, a swimming pool. A Club life in colonial India was like, building with a large number of popular sports facilities including a cricket ground and a swimming pool. It also includes accommodation for the club members. Other facilities in the clubs are games rooms like carom board, badminton, squash, table tennis, billiards, chess, air conditioned bars, dining halls, banquet halls as well as a number of lawns for large gatherings and parties. Sometimes with large food court that provides a multitude of cuisines. The roll call of clubs that followed; the pioneering Calcutta Cricket Club is long and distinguished. The Bombay Turf Club (for horse racing) was founded in 1800, the Bengal Club (1827) in Calcutta, the Royal Calcutta Golf Club in 1829(making it oldest golf club outside Britain), the Madras Club (1832) in then Madras Presidency, the Byculla Club (1833) in then Bombay, The Calcutta Rowing Club in 1858, the Bangalore Club in 1868, the Bombay Gymkhana Club in 1875 and several more in towns and outposts. Club Life' in colonial India was, despite its initial phases of exclusiveness, for over a century and more since the "earliest and largest social clubs" - came into being were little known but structurally key crucibles of change in modernizing and secularizing the Indian tradition (Chatterjee, P. 2015)(Fig. 3)(Fig. 4).

There were then newer clubs like the 'Union Club of Calcutta (1859)', the 'Hyderabad Boat Club' established in 1877, the 'Calcutta Club' formed in 1907 two years after the infamous partition of Bengal, the 'Cosmopolitan Club' that came up in Mysore in 1896, and among others, two other 


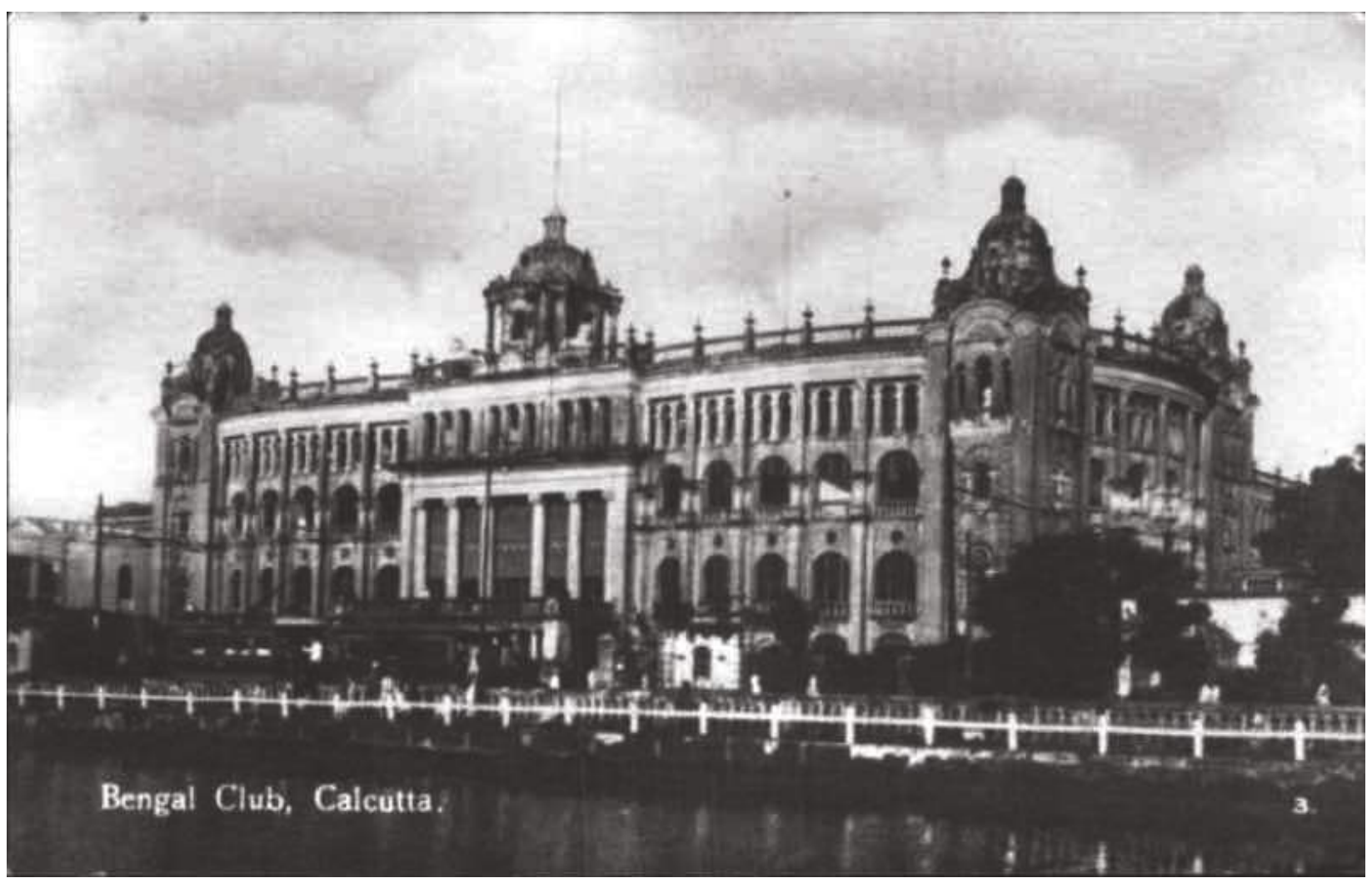

Figure 3. The Bengal club, Calcutta (Source: http://noisebreak.com/heritage-cubs-calcutta-tales-bengal club/).

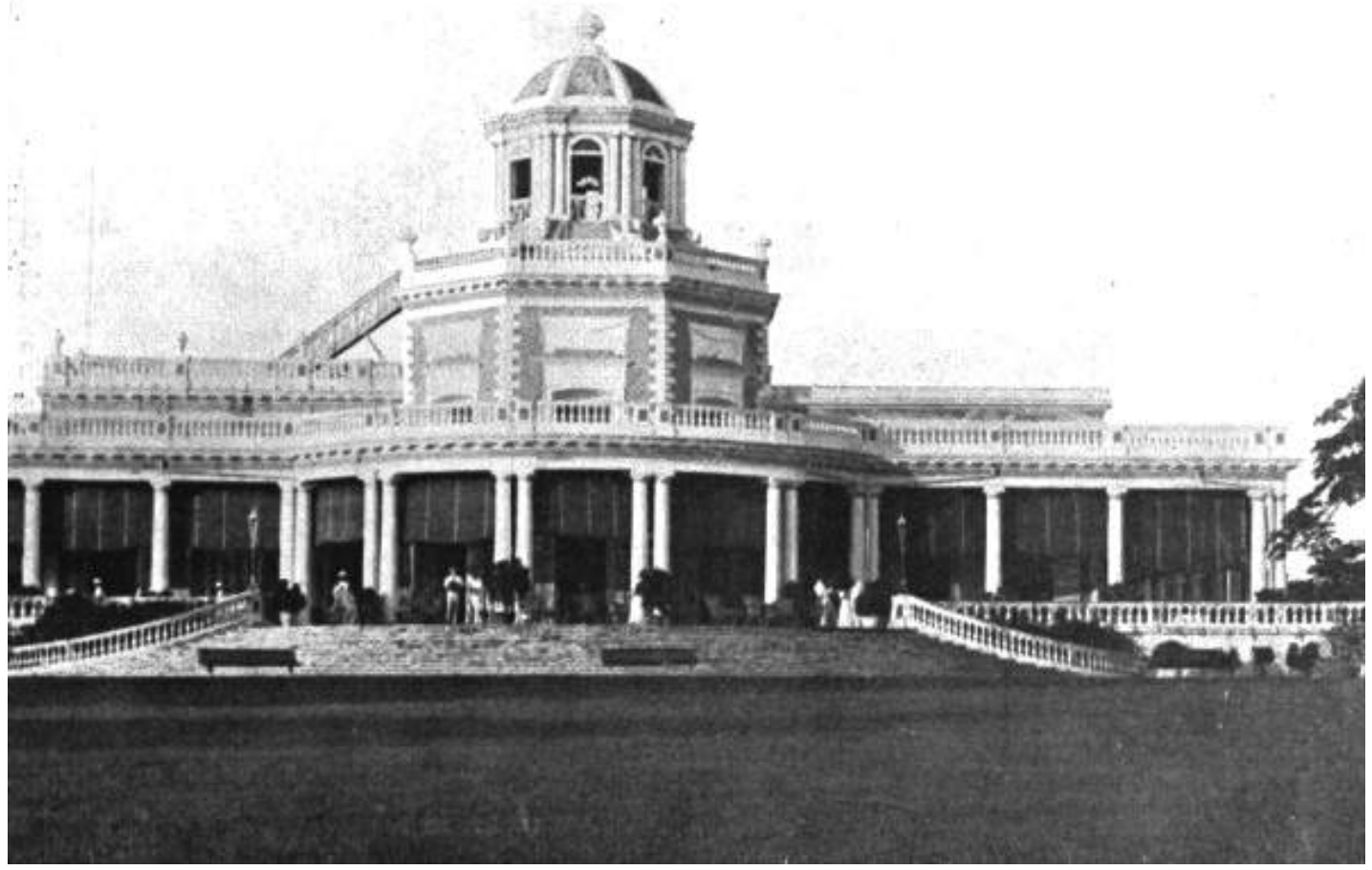

Figure 4. The Madras Club (1832) (Source: http://madrasmusings.com/Vol\%2019\%20No\%2012/historic_residences_of_chennai_27.html). 
famous clubs that Mokshagundam Vivesvaraya promoted the 'Deccan Club' in Pune (1891), and the 'Century Club' in Bangalore (1917). Indians themselves formed several clubs including those blessed by the princely states scions.

In sports activities also, The British, it's often said, have a particular genius for inventing sports and games. During colonial period, sports was not only the way of personal development and fitness, however it was the source of leisure and entertainment also. It was also a means through which they interact among social classes and also get opportunity to communicate with native people. Colonials believe in the social classes and sports was a platform which provide social mobility in the earlier Britain and Asian countries. Throughout the Empire Cricket became symbolic of the Imperial spirit. For urban working class society's football was also extremely engaging sport. In some sports, there was vital argument also in the fight for amateur purity. Many of the new games were introduced which became popular overnight, including golf, lawn tennis, cycling and hockey. In eighteen century, among the English upper class Cricket had become well-established sport and was a major factor in sports competition (Chatterjee, P. 2015).

\subsection{Origin of cricket in British India}

Cricket was recorded as having been played in India as early as 1721.After the invention of sea routes, British sailors used to visit Indian coasts for trade .one day in 1721, the British ship dropped at the coast of Kutch in western India. For free time entertainment, the sailors of the merchant ship were indulged in playing cricket. British sailors did not had idea that their carefree game was to be the very first act of revolution of cricket in India. The game which they played for entertainment only becomes the first recorded reference of cricket in India. ("Visual Documentation of Socio-cultural ethos", N. Date)(Fig. 5) Later on when the merchant became rulers, they continue to establish their recreational activities on Indian soil and in 1751, first recorded cricket match was played in India. Although most clubs' early records have been lost, the existence of the first Indian Cricket Club was found in 1792; it was called Calcutta Cricket Club. At the beginning, there were no permanent ground for playing matches. The Calcutta Cricket Club played its games on the walkway, which is parallel with the river Hooghly. By 1820, the members of

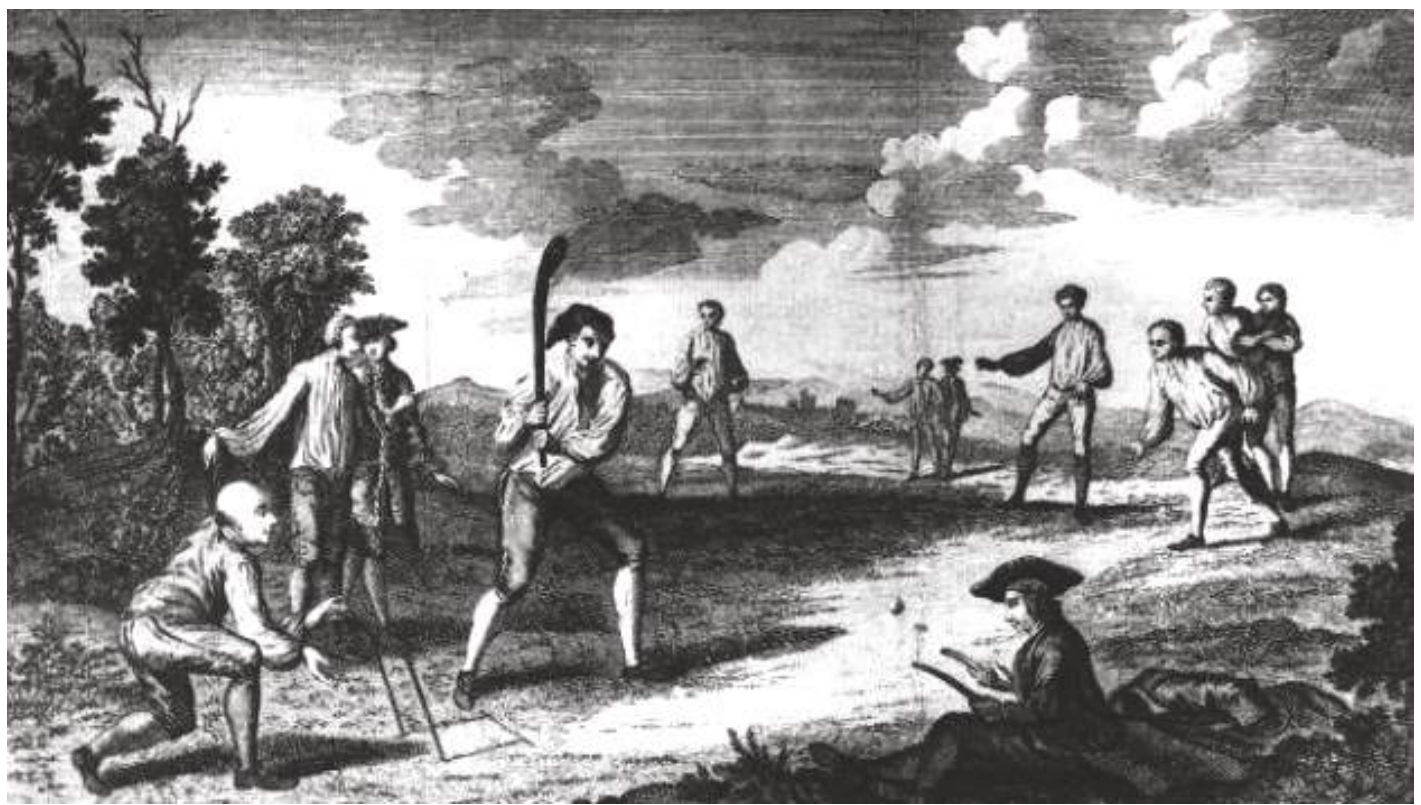

Figure 5. Sailors of the merchant ship playing cricket (Source: http://www.cricketcountry.com/articles/1721-the-earliest-mention-of-cricketin-india-182681).

the club felt that they need their own ground which has to be permanent. Then In 1825, the Calcutta Cricket Club succeeded to use the land permanently on the Maidan. Then in 1841 the club as relocated to the eastern boundary of the Auckland Circus Gardens.

Initially the game was played among Englishmen only and Indians who used to watch the game as spectators were gradually attracted by it and learnt the art of playing cricket. Five years later Bombay hosted its first match and in was in Bombay that Indian first began to play the game. As years rolled by and the 'Swadeshi' movement stared, the native Indians also entered into the game (Sharma, P. 2011). Bombay is unquestionably the birth place and homeland of Indian cricket. It was in Bombay the Indian cricket was born. 
The Parse's were the pioneers of the fame and organized the first club, the Orient Club, in 1848. Parse's were the fire worshippers. They fled their native Persia when the Islam taken over almost the entire Persia and they settled along the coast of Western India. Unlike other Indian communities, the Parse's quickly took to western culture, their music and their English language as well. With their flexible and attractive character, they took willingly to cricket also. Whereas the Calcutta Cricket Club, mostly a European affair, had been founded by the then Indian Country Army Officers and men figured as the main players of the Cricket Team (Fig. 6).

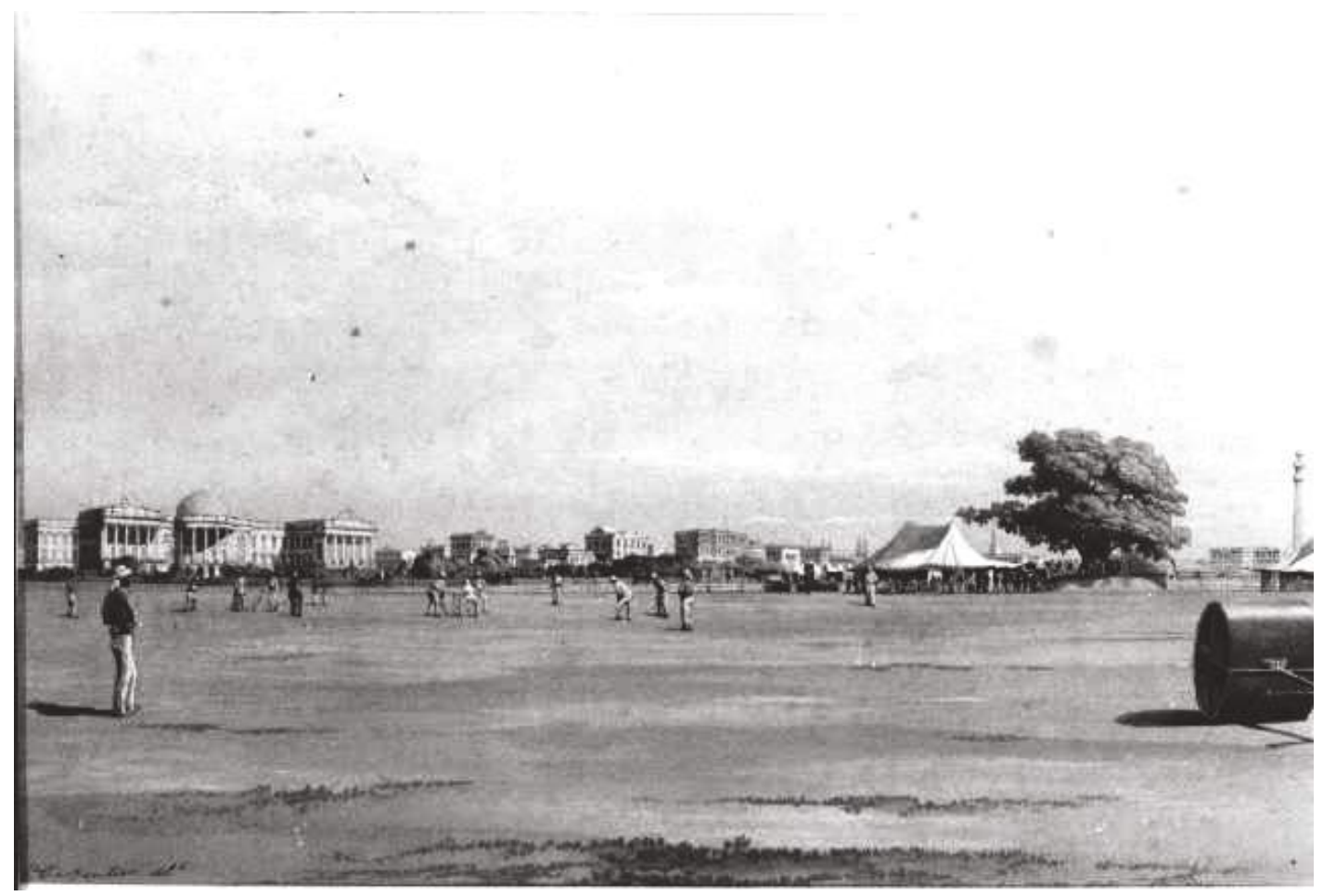

Figure 6. Calcutta Cricket Club (Source: https://puronokolkata.com/category/gallery/establishments/socio-cultural-institutions/sportsrecreation/).

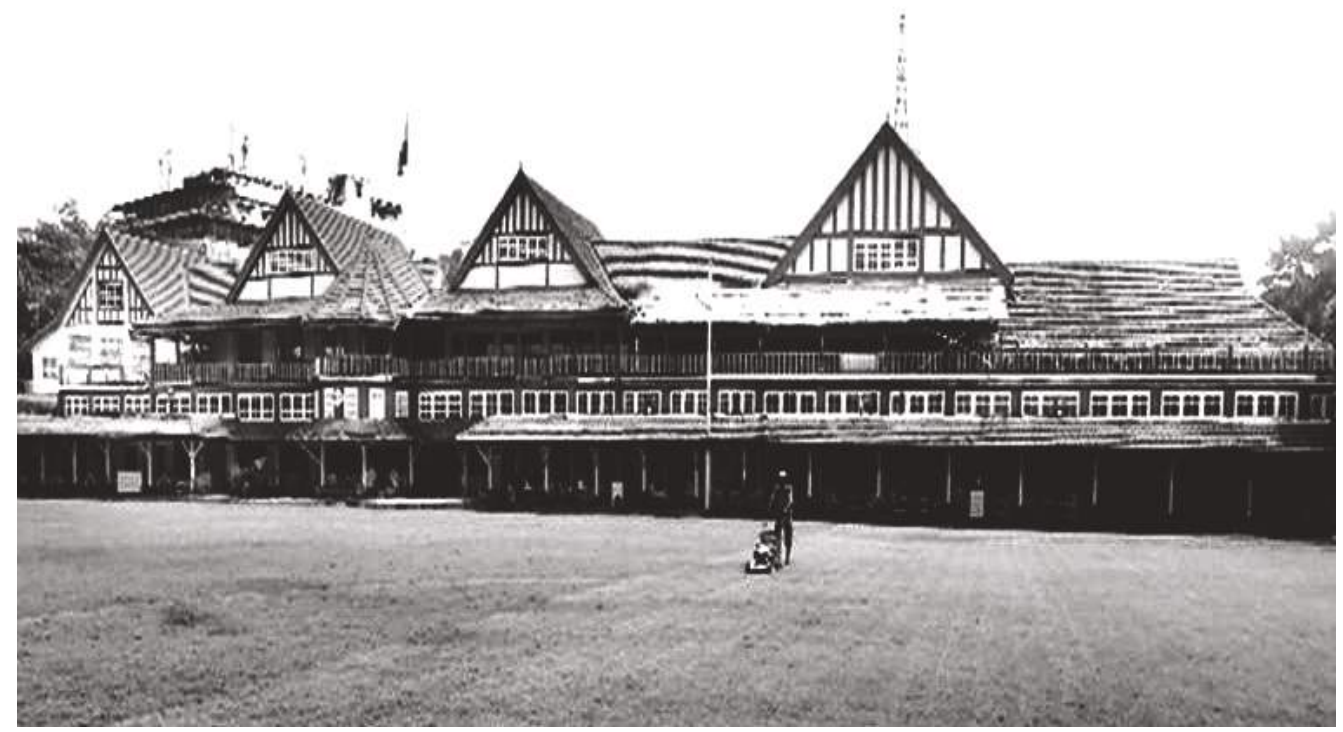

Figure 7. The first construction was the pavilion, a temporary structure, which was completed by March 1876 (Source: http://indianexpress. $\mathrm{com} /$ article/cities/mumbai/once-upon-a-time-bombay-gymkhana-was-first-club-to-bring-multiple-sports-together-2988064/). 


\subsection{Remarkable Cricket stadiums of British India}

\subsubsection{Bombay Gymkhana Club cum stadium}

Bombay Gymkhana Club: The first temporary structure of Bombay Gymkhana Club was completed in March 1876 that was the pavilion building .During that time , the only Indian allowed in the club were the servants. Pavilion was a single storied structure measuring the size $100^{\prime} \mathrm{X} 50^{\prime}$ rectangular central hall. Activities in the main central hall were badminton courts, locker rooms for the members and a general club, where the facility of bar was provided. In 1877, Gymkhana club got extra land adjoining the pavilion, by this now they were able to expand the other recreational activities like Rollerskating and a garden for ladies nights parties. Here, the cricket matches were plays only during the monsoon period, even though the cricket was the most popular sport. Other than monsoon period the entire cricket ground was used only for Army Parade. But after 1901, gymkhana Club stated organizing cricket matches in winter seasons also (Sharma, P. 2011)(Fig. 7).

\subsubsection{Chail Cricket Ground, Chail, Himachal Pradesh}

Chail is situated around $45 \mathrm{~km}$ from Shimla, which is the capital of Himachal Pradesh. In 1893, Maharaja Bhupinder Singh, Maharaja of Patiala, established the Chail cricket ground. The time when the ground was made, Chail was the summer capital of maharaja. This ground is recorded as a highest cricket ground in the world, measuring $2444 \mathrm{mts}$. above sea level (Chail Cricket Ground, 2017).

\section{Origins of the Chail Cricket Ground}

In 1891, during the British Raj, Maharaja Bhupinder Singh of the royal family of Patiala provoked Lord Kitchener to anger, which led to the Maharaja being banned from entering Shimla, which was the summer capital then. The Maharaja then made Chail his summer capital and rebuilt the place as per his needs. He built the cricket ground in 1893 by levelling a hilltop. The Maharaja was a cricket lover and used the Chail Cricket Ground to play friendlies. After the formation of the Union territories, the then Maharaja of Patiala gave all the buildings and the ground to Military School at Chail and the Government. The Chail Military School started using this ground as a school playground. During the school Vacation, the ground is sometimes used to play polo. Within the ground there is also a well-maintained basketball court. Occasionally, even football is played on the ground as there are goal posts present (James, D. 2015)(Fig. 8).

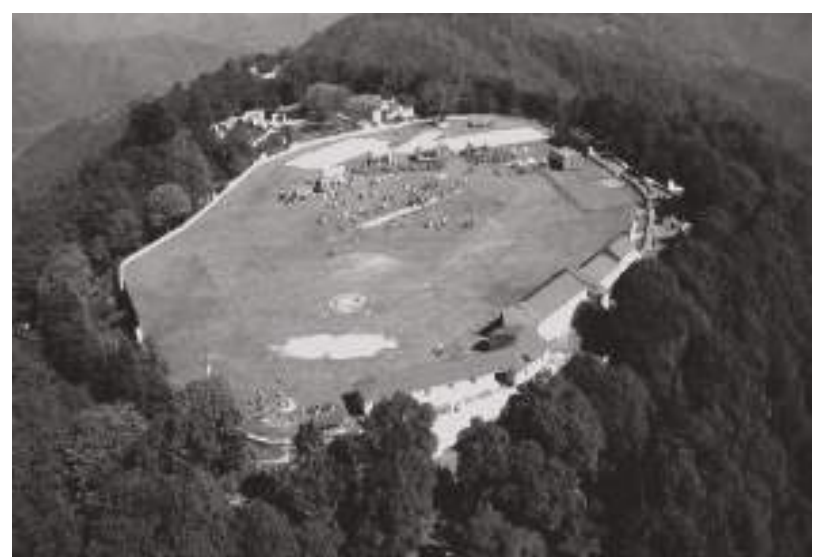

Figure 8. Cricket ground at Chail, Himachal Pradesh (Source: https://www.sportskeeda.com/cricket/worlds-highest-cricketground-stadium-built-even-higher).

\subsubsection{Eden Gardens cricket stadium, Kolkata}

Eden Garden cricket stadium is situated in Kolkata, India. It was established in 1864 during the time of Lord Auckland when he was the Governor General of India. This is recorded as one of the largest cricket stadium in India made by British's. The ground hosted many matches since 1864 and it is also known as "cricket's answer to the Colosseum". The name of the ground is taken from the oldest park in Kolkata 'Eden Garden' which was designed in 1841. The stadium consist of club house, which is situated on the south side of the ground, offices for cricket associations, players rooms, umpire rooms etc. It can accommodate over 66,000 people at a time. The main structure is made out of R.C.C. frame and steel structure used at upper level. Till now, this stadium has been developed in various phases of renovation (Eden Gardens, 2017)(Fig. 9)(Fig. 10).

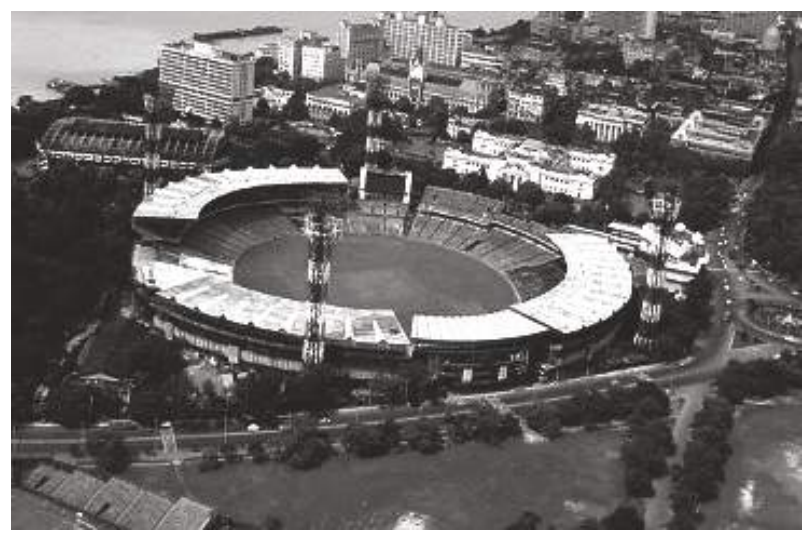

Figure 9. Aerial view of Eden Gardens Cricket Stadium, Kolkata (Source: http://www.india.com/travel/articles/7-facts-about-kolkatasiconic-eden-gardens-stadium-that-will-make-every-indian-proud). 


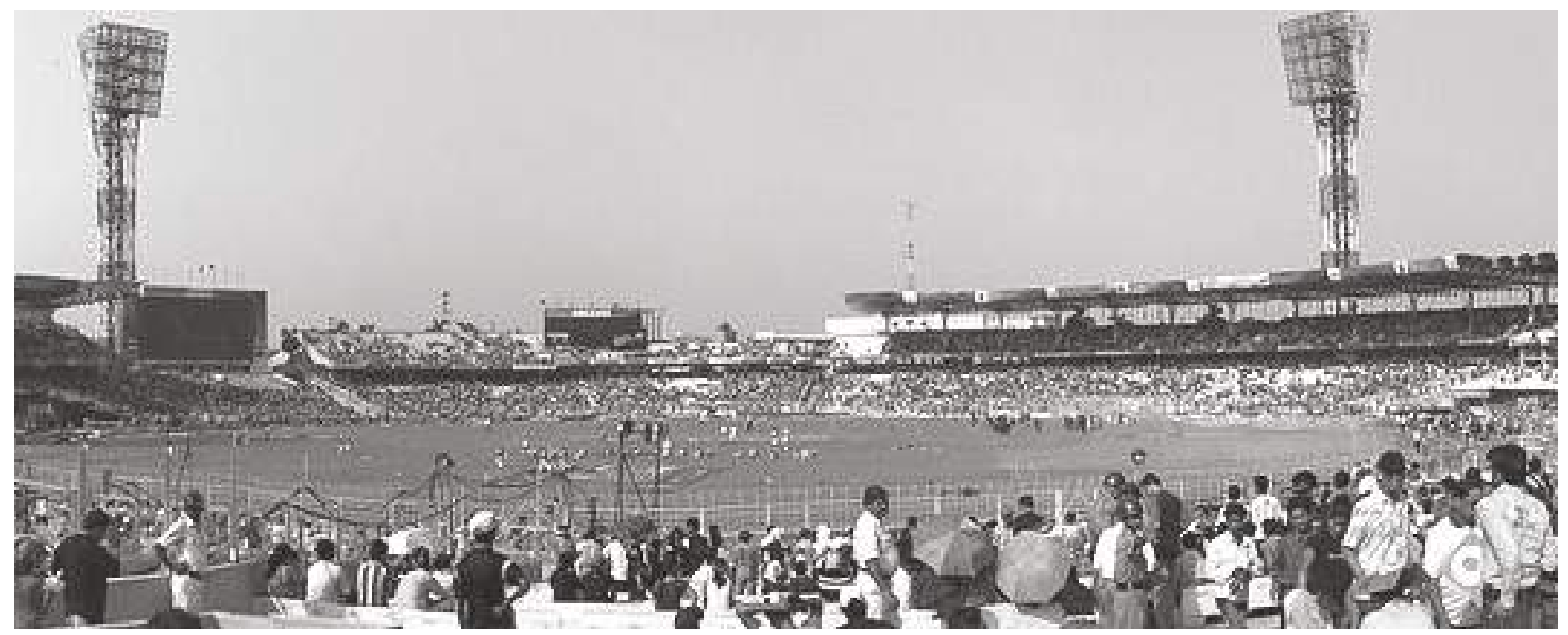

Figure 10. Spectators overlooking the Stadium Ground (Source: http://kolkatacitytours.com/eden-gardens-stadium-kolkata/).

\section{Princely States Maharajas and Their Interest in Cricket}

\subsection{Princely States}

Under the British rule, India was divided into two types of administrative systems. One system comes under the category of 'Provinces' and the other system was 'Princely States'. Concerning hour of the Indian Sub - continents territory were provinces and only $40 \%$ were the princely states. All the Provinces were comes under the management of Britishers, whereas Princely states were also states in British India but their ruler were the local Maharajas, Raja, Nawaz or any other title which means the ruler in different Indian languages and these rulers were subjected to the British Empire. These two types of administrative systems were result of the British East India Company's attempt to cover the whole of Indian sub -continent and make it into a British territory (Indian History, Princely States and Provinces)(Fig. 11).

\subsection{Sports and Princely States Maharajas}

If we leave aside the Parsi obsession with cricket, the Indian royals were the first group of Indians to take up sports in an organized manner. The Indian Princes, of course, had a long tradition of martial sports such as hunting and riding. In 1928, the president of Indian Olympic Committee, Sir Dorabji Tata, lamented to the head of International Olympic Committee that in India the maharajas 'take interest chiefly in shooting, hunting and polo. But just as many of the maharajas began going to English -run public schools in the late $19^{\text {th }}$ century they also started taking up English sports, cricket.

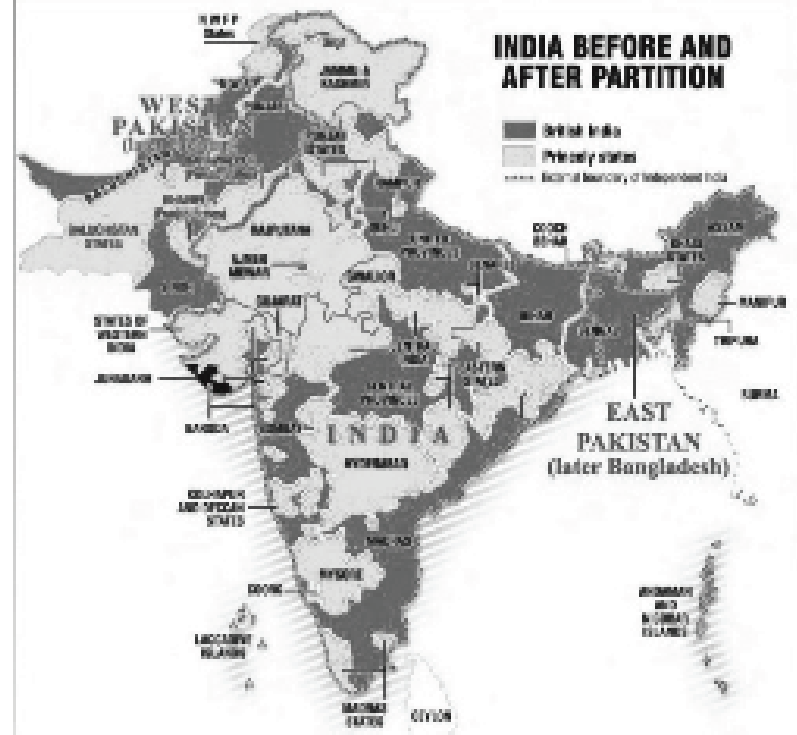

Figure 11. Map showing princely states and provinces (Source: https://selfstudyhistory.com/2015/01/18/post-independent-indiaintegration-of-princely-state/).

\subsubsection{Patiala: The sports capital and its Maharajas}

Patiala city was founded in 1757 AD by Baba Ala Singh and it was one of the youngest city of the re-organized Punjab. Patiala has rightly been called the cradle of sports since British period. Maharaja Rajinder Singh, Bhupinder Singh and Yadwinder Singh called the first sporting citizens of the country. During the region of Maharaja Rajinder singh, ( $7^{\text {th }}$ maharaja of Patiala) Patiala started its great tradition in modern games, particularly cricket. The next ruler maharaja Bhupinder Singh, continued his interest in cricket and 
invited to Patiala great English cricketer of the time (The Cricket Club of India) (Fig. 12)(Fig. 13).

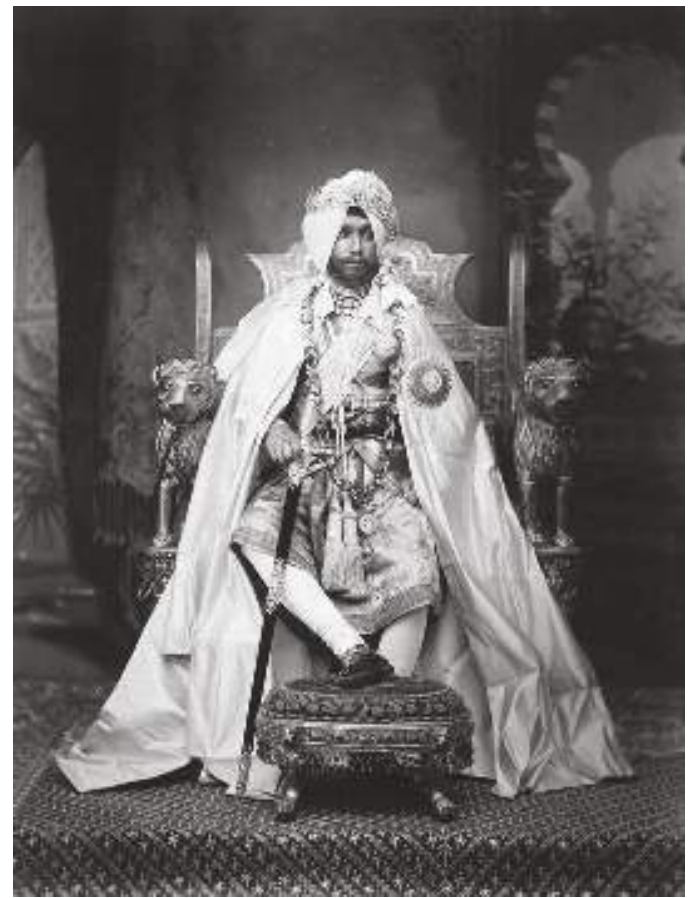

Figure 12. Maharaja Rajinder Singh (Source: https://en.wikipedia. org/wiki/Rajinder_Singh).

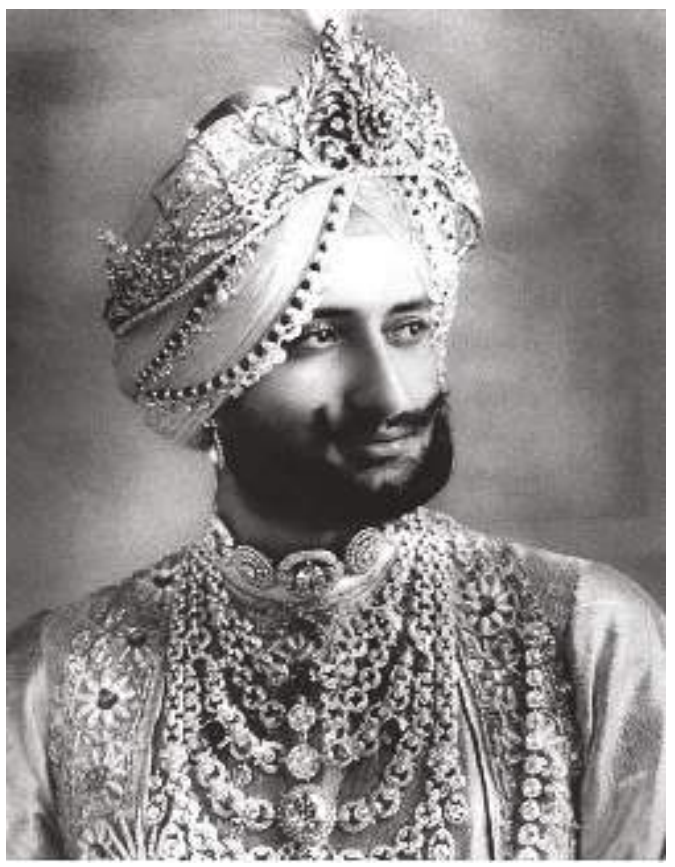

Figure 13. Maharaja Bhupinder Singh (Source: http://www. mensxp.com/special-features/today/32709-this-badassmaharaja-led-a-lifestyle-that-even-dan-bilzerian-would-bejealous-of.html).
Great cricket matches were played on the famous Patiala gymkhana ground located in the Baradari gardens and at the Chail cricket ground in Shimla, which still has the proud distinction of being the highest cricket ground in the world (James, D. 2015). The royal family of Patiala also contributed in a big way to constructing the Brabourne Stadium in Mumbai and Southern Pavilion in Amritsar (Fig. 14)(Fig. 15)(Fig. 16). The contribution of Indian Princes in promoting and patronizing the game in and outside their states cannot be underrated. The house of Patiala which had taken keen interest in the game right from 1890. Maharaja Rajendra Singh not only built Cricket ovals in Patiala and Chail, but also invited Brockwell and Heame from England to Coach Indian Cricketers. His Successor Raja Bhupinder Singh continued to patronize the game (Sarkar, A. 2016).

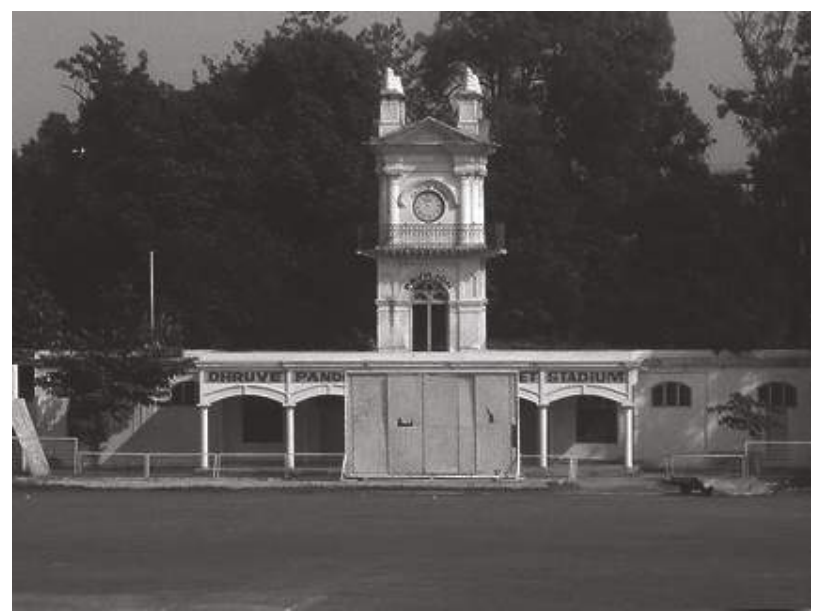

Figure 14. Dhruve Pandove Stadium at Baradari garden, Patiala (Source: Clicked by Author).

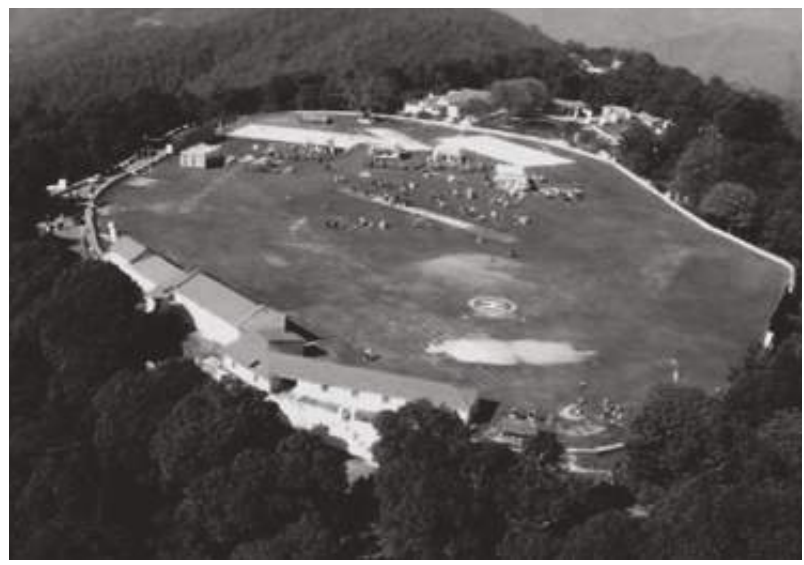

Figure 15. ChailCricket Ground, Himachal Pradesh (Source: https://www.tourmyindia.com/images/chail-cricket-ground 1.jpg). 


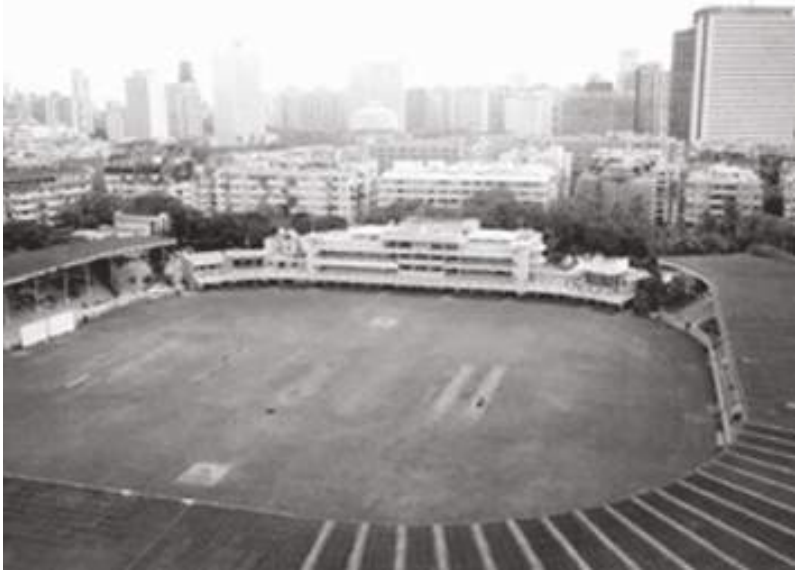

Figure 16. Brabourne Cricket Stadium, Mumbai (Source: http:// timesofindia.indiatimes.com/india/Patiala-royals-endorsed-cricketin India/ articleshow/7525504.cms).

\subsubsection{Maharaj Kumar Anand of princely state Vizianagaram}

Along with the name of the Patiak Princes name that stands out prominently is that of Maharaj Kumar Anand of Vizianagaram. He was popularly called "Vizzy". He collected the best of players from all over the country and invited Hobbs and Sutcliffe, the reputed English opening pair to join his team and took his Team to various centers. It was at his instance that playing of cricket was introduced in Mysore, Banglore and the Southern part of the country (Fig. 17).

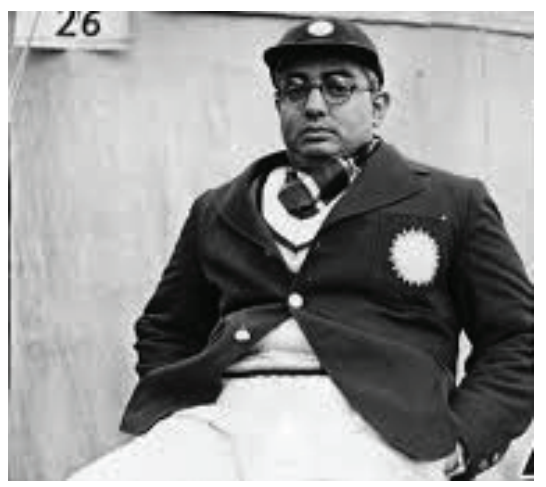

Figure 17. Maharaj Kumar Anand, Vizianagaram (Source: https:// www.google.co.in/search?client=opera\&q=Maharaj+Kumar+Ana nd + of+Vizianagaram\&sourceid $=$ opera\&ie=UTF-8\&oe $=U T F-8)$ ).

\subsubsection{Maharaja Ranjitsinhji Vibhaji, ruler of the Indian princely state of Nawanagar in Kathiawar (in present-day Gujarat):}

He was a flamboyant cricketer who studied at Cambridge University and played for the Sussex cricket team in first- class county competition. He later served as the county team's captain too. What's more important is the fact that Ranji, as he was popularly known, went on to become the first Indian to play cricket for England. India's most prestigious domestic cricket tournament - the Ranji Trophy, is named after him. He, indeed, was Indian cricket's first superstar. Born in 1872 in Sadodar, Gujarat, he was the ruler of Nawanagar from 1907 - 1933, until his death (Khare-ghose, A. 2016) (Fig. 18).

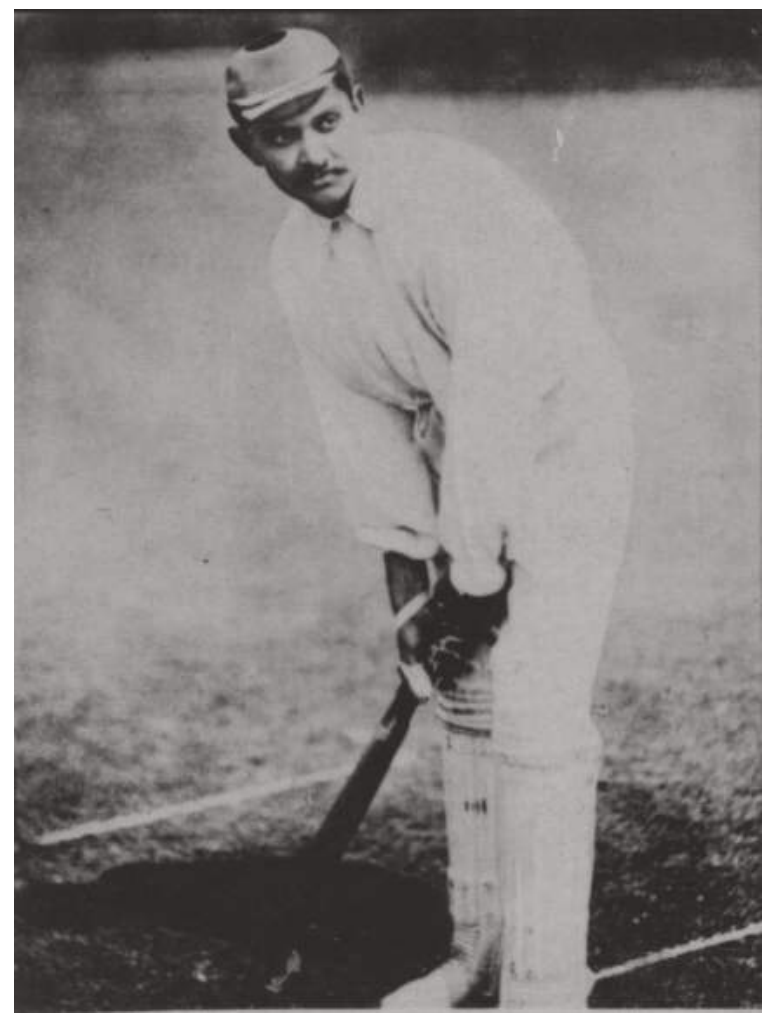

Figure 18. Maharaja Ranjitsinhji Vibhaji, Nawanagar, Gujarat (Source: https://en.wikipedia.org/wiki/Ranjitsinhji).

\section{Dhruve Pandove Stadium Cum Gymkhana Club, Patiala}

The time when there was not any cricket ground in Patiala, The then Maharaja of Patiala Rajinder Singh, once visited the Bombay Gymkhana Club to watch a cricket match held there. But the European, who enjoyed a separate enclosure and did not liked any Indian to sit along with them, they informed the maharaja that he could not sit among us. This incidence hurt and distressed Maharaja and then he decided to create his own cricket ground where no such practice existed.

In 1890 'Gymkhana Club cum Stadium' at Patiala, Punjab was built by Maharaja Rajinder Singh. Maharaja Rajinder Singh, a passionate cricketer, constructed a cricket pavilion and it was named Patiala Cricket Club.In 1920 in 
the club various other sports were added and the name was also changed to Rajindra Gymkhana Club (Majumdar, B. 2008).

\subsection{Gymkhana Club cum Stadium}

\subsubsection{Description}

Gymkhana club also named as Rajindra Gymkhana and Mahindra club is located within the Baradari gardens. There is a railway track on the north side of the gymkhana club .and there is flyover on the west side. On the other two sides it is approachable through Baradari garden roads. The whole area is clubbing two function. One is club building, which was earlier the royal residence now it comprises restaurant, bar, games room and another is cricket stadium which comprises cricket ground and stadium building named as Dhruve Pandove cricket stadium. The stadium has a separate entry from club building and it has two entrances, out of which one is now closed. All around the stadium there are spectators place the stadium has no direct link with club building (Fig. 19).

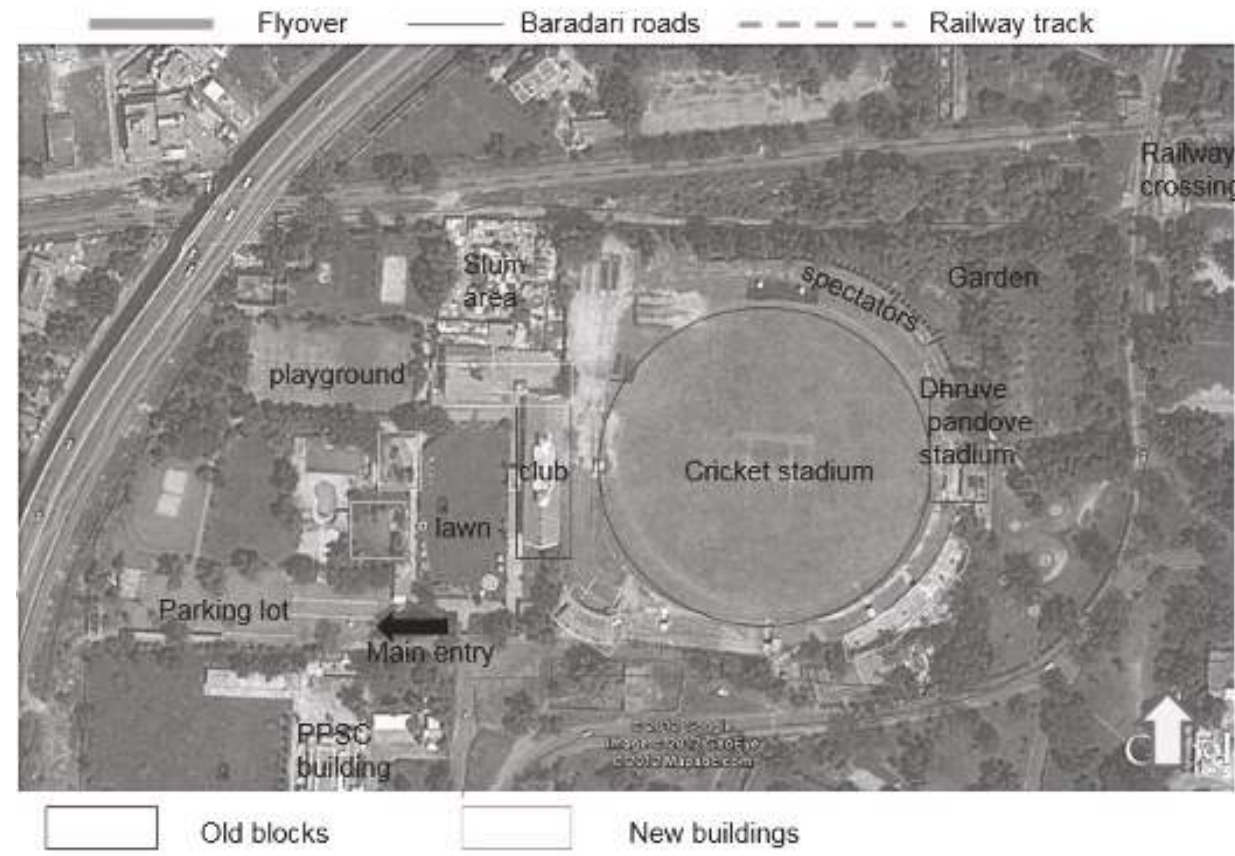

Figure 19. Site surroundings of Gymkhana Club cum Stadium (Source: Adapted by author from the Google Earth image).

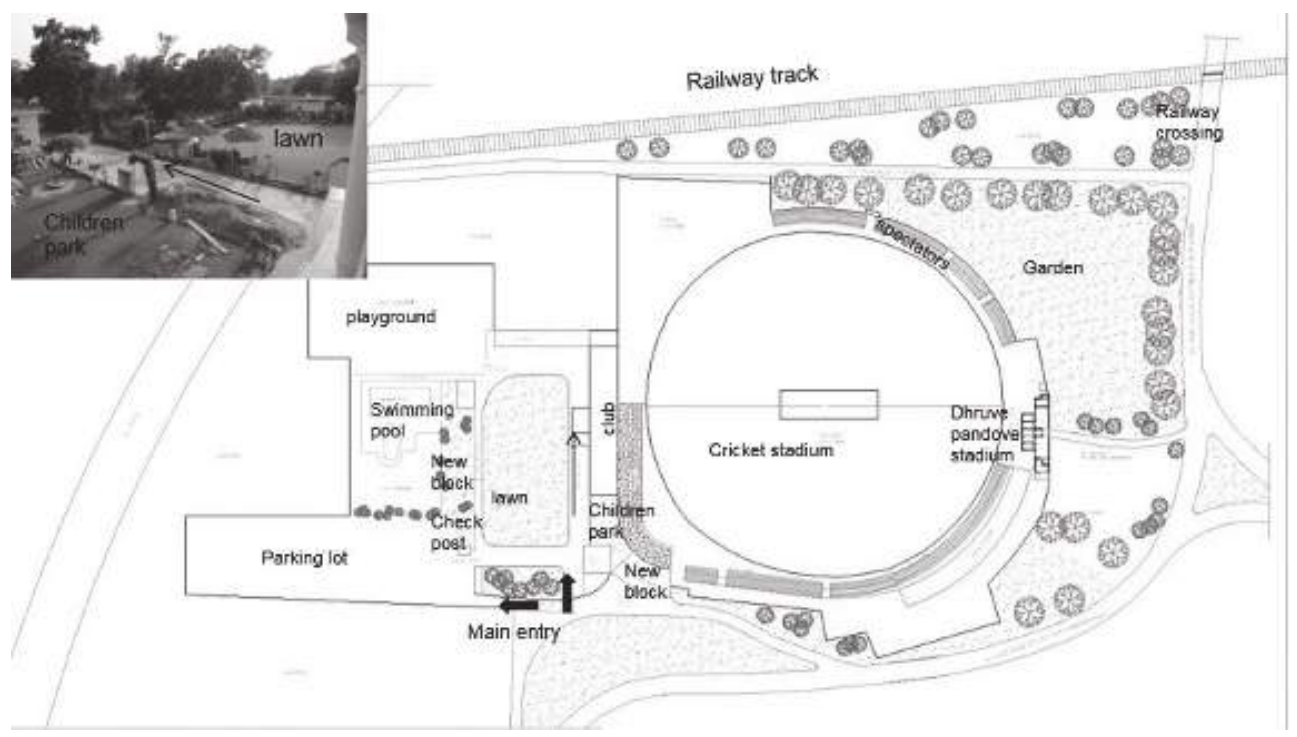

Figure 20. Site plan of Gymkhana Club cum Stadium (Source: Prepared by Author). 


\subsubsection{Site features:}

There are two entrances to the club building and one is to the stadium. As we entered into the club building there is a parking lot, after crossing the check post we can entered into the club building by crossing the lush green lawn. The site contain the old club building earlier which was the royal residence, apart from this there are other new blocks constructed (Fig. 20).

\subsubsection{General planning of club building:}

The plan of the building is linear in shape with only one main entrance situated at the middle of the longitudinal side. The entrance of the building has a huge porch with the same arches as in the façade of the building. The porch is totally supported on columns and has a separate structure from the building. Both the longitudinal and shorter elevations are very similar. The complete façade has a similar pattern of columns and arches that are running all along the external wall. The rear side has a corridor facing the cricket ground with a jali to protect the viewers. The room is a sloping roof make of wooden battens and covering. The style of arches and elements makes it a colonial style of building. There are big dining halls both at the ground and the first floor for get together purposes and are open the members of the club as well. The doors of the halls are opening to a straight corridor running on both the side of the first floor. All the halls are provided with a fire place with chutes seen atop of the roof (Fig. 21)(Fig. 22)(Fig. 23).

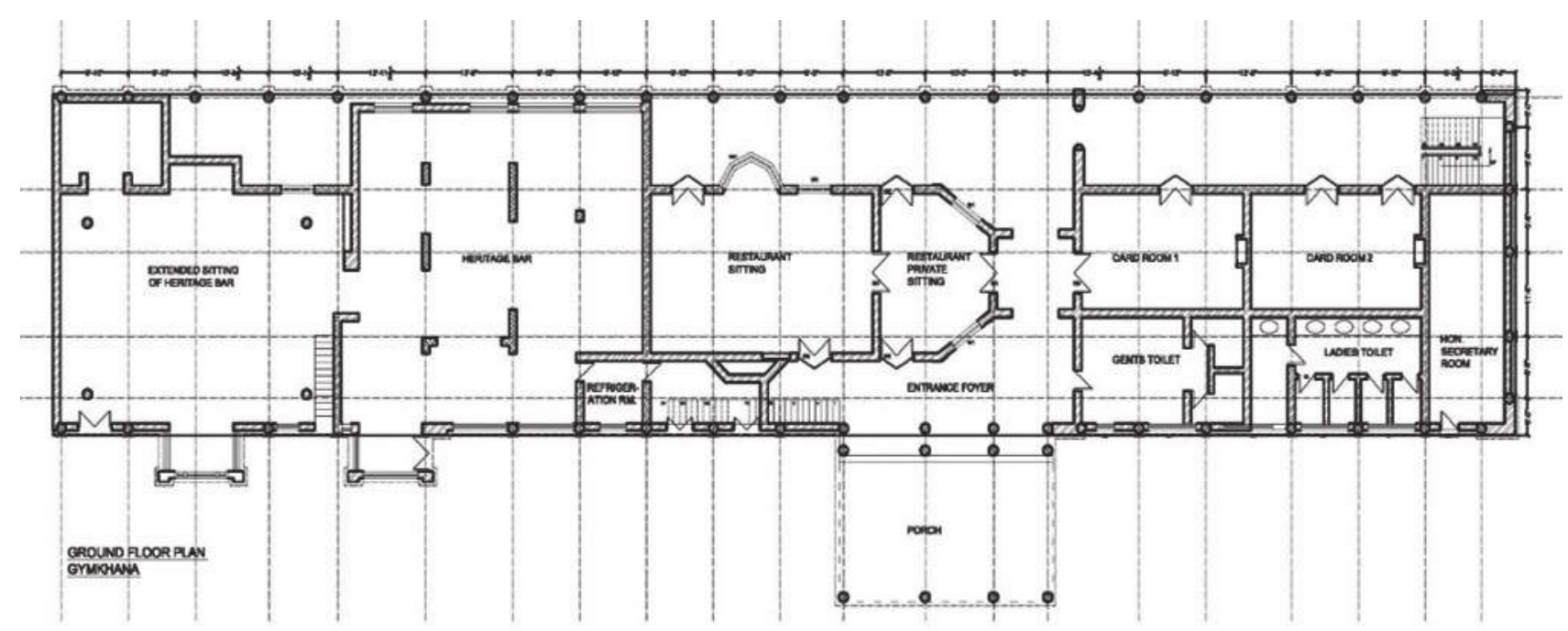

Figure 21. Ground floor plan (Source: Prepared by Author).

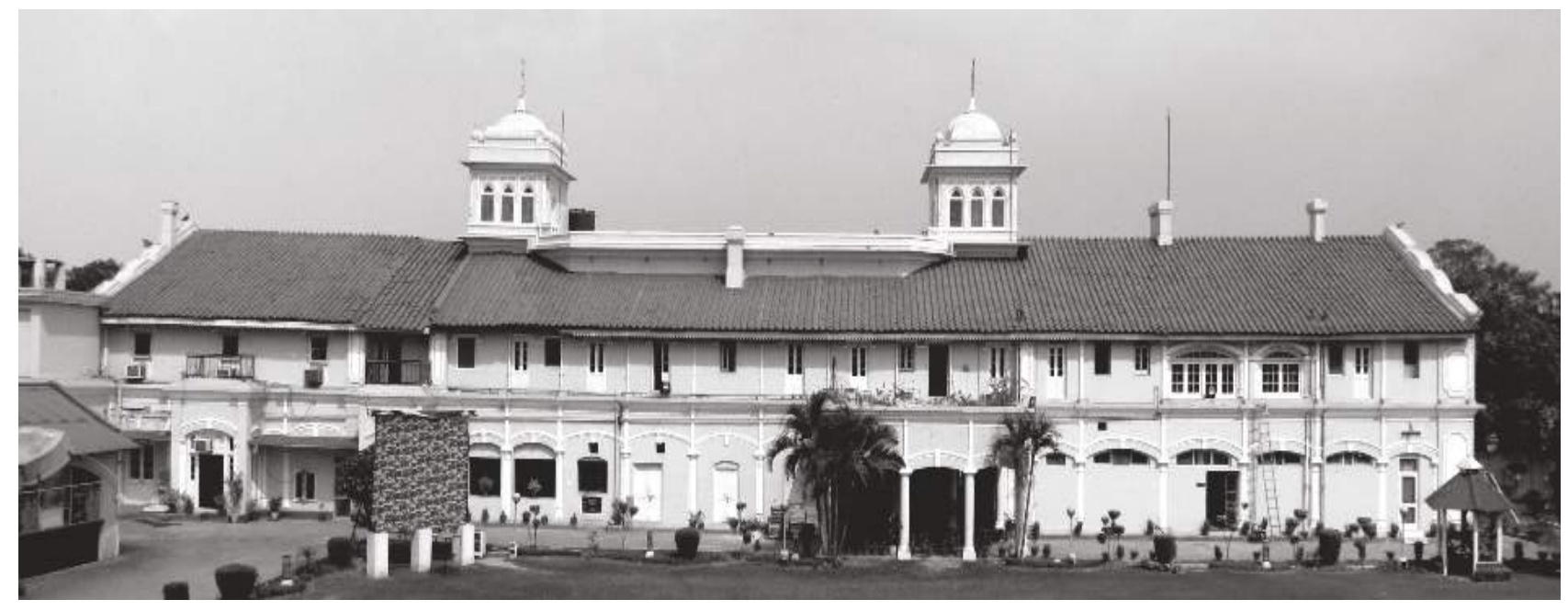

Figure 22. Front Elevation (Source: Clicked by Author) 


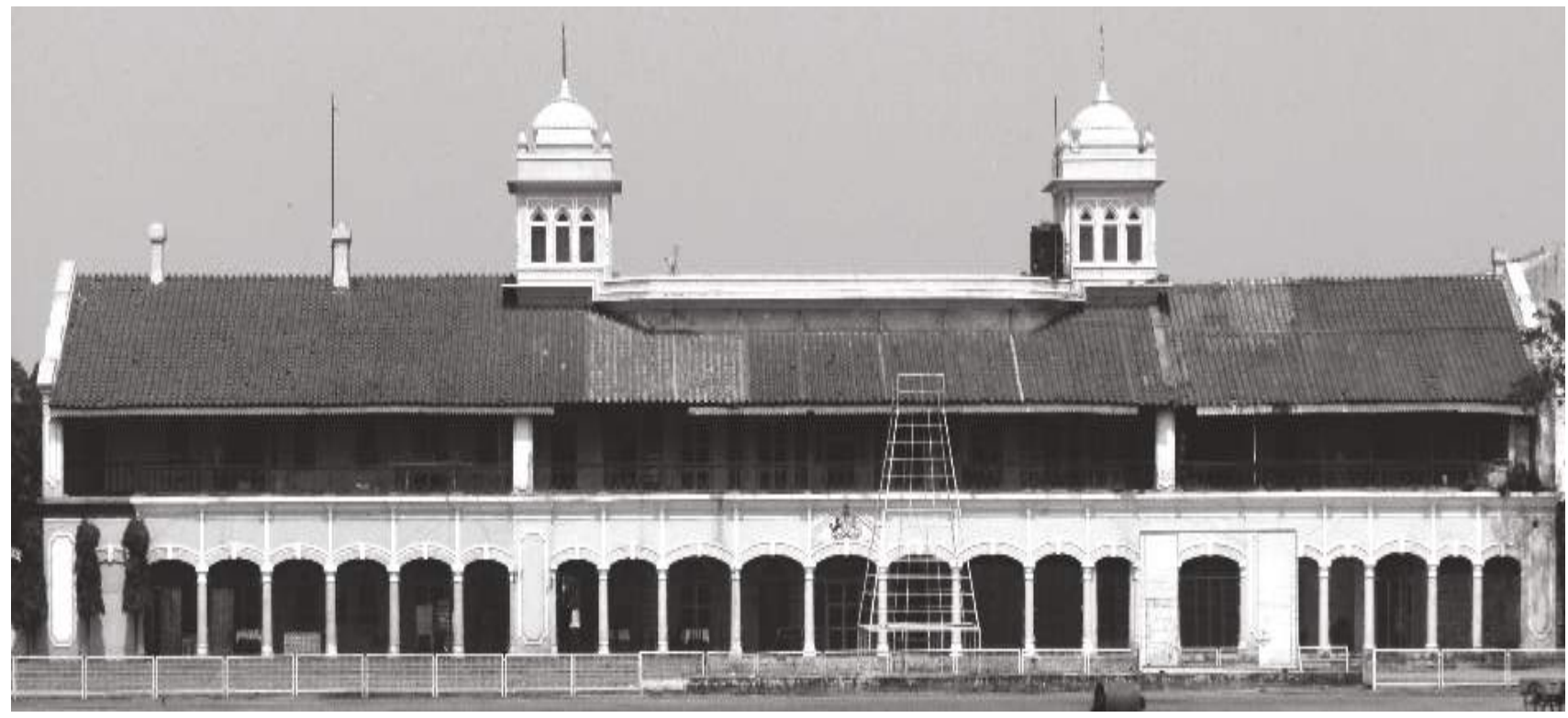

Figure 23. Rear Elevation (Source: Clicked by Author).

\subsection{Dhruve Pandove Stadium}

General planning:

This is a single storied building having a linear planning (Fig. 24). Originally this building was designed as a stadium and earlier its entry was from a back side. Now new porch is added which is act a main entrance now days. At front of the building there is a huge cricket stadium with spectators all around. There is a tower at the center which is two storied high, giving this building a unique identification (Fig. 25) (Fig. 26).

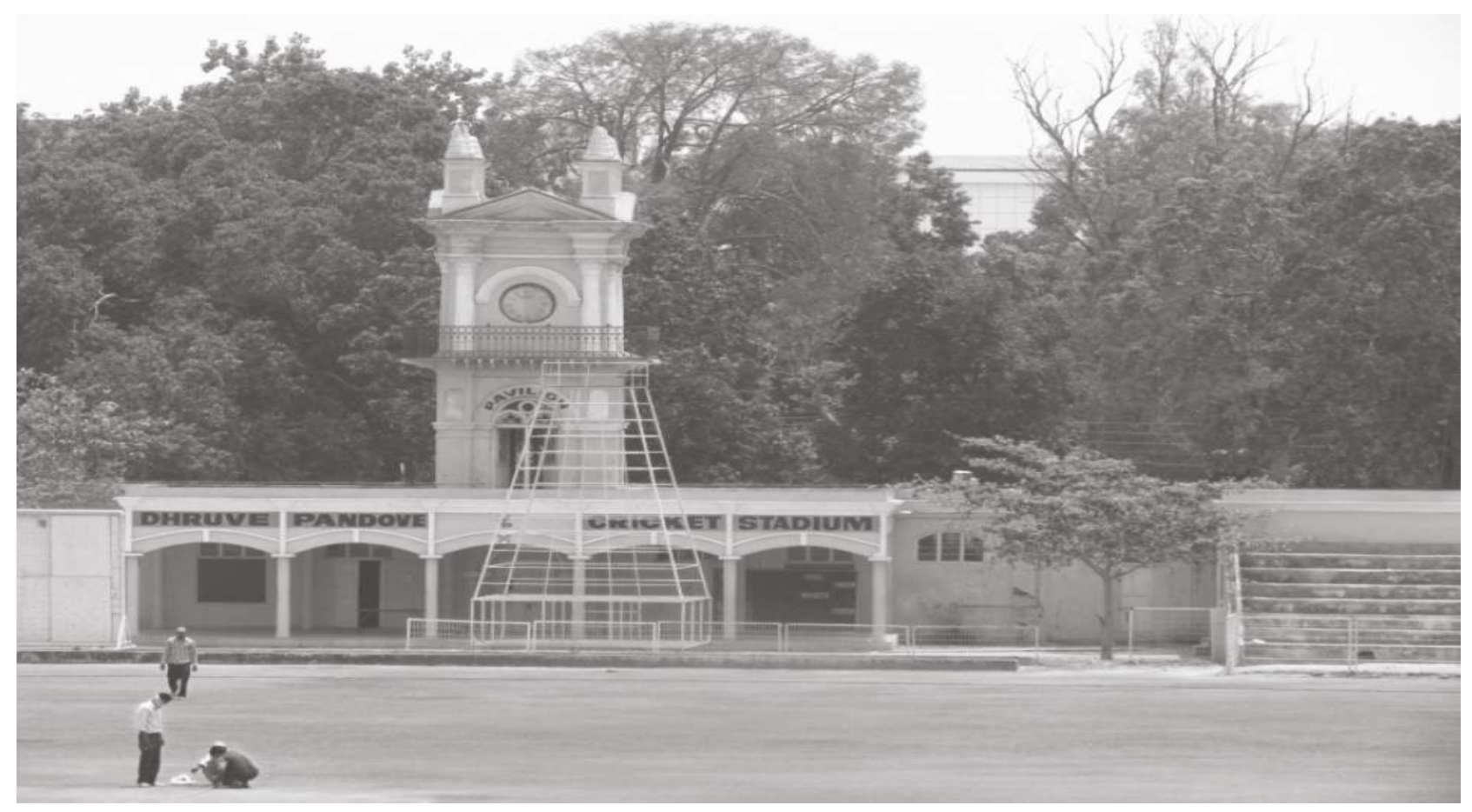

Figure 24. DhruvePandove Pavilion cum Stadium (Source: Clicked by Author). 


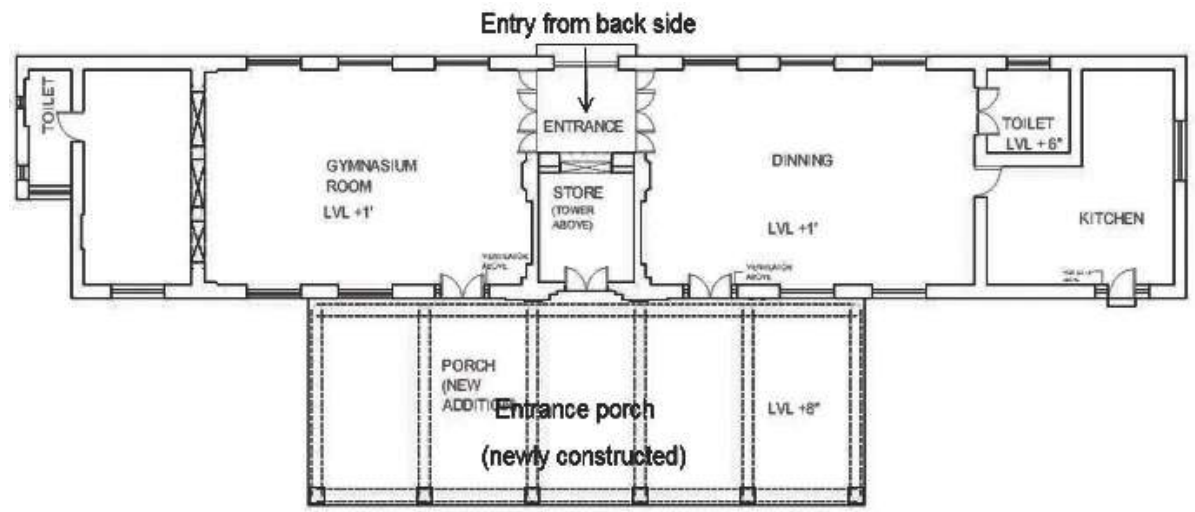

Figure 25. Ground floor plan (Source: Prepared by Author)

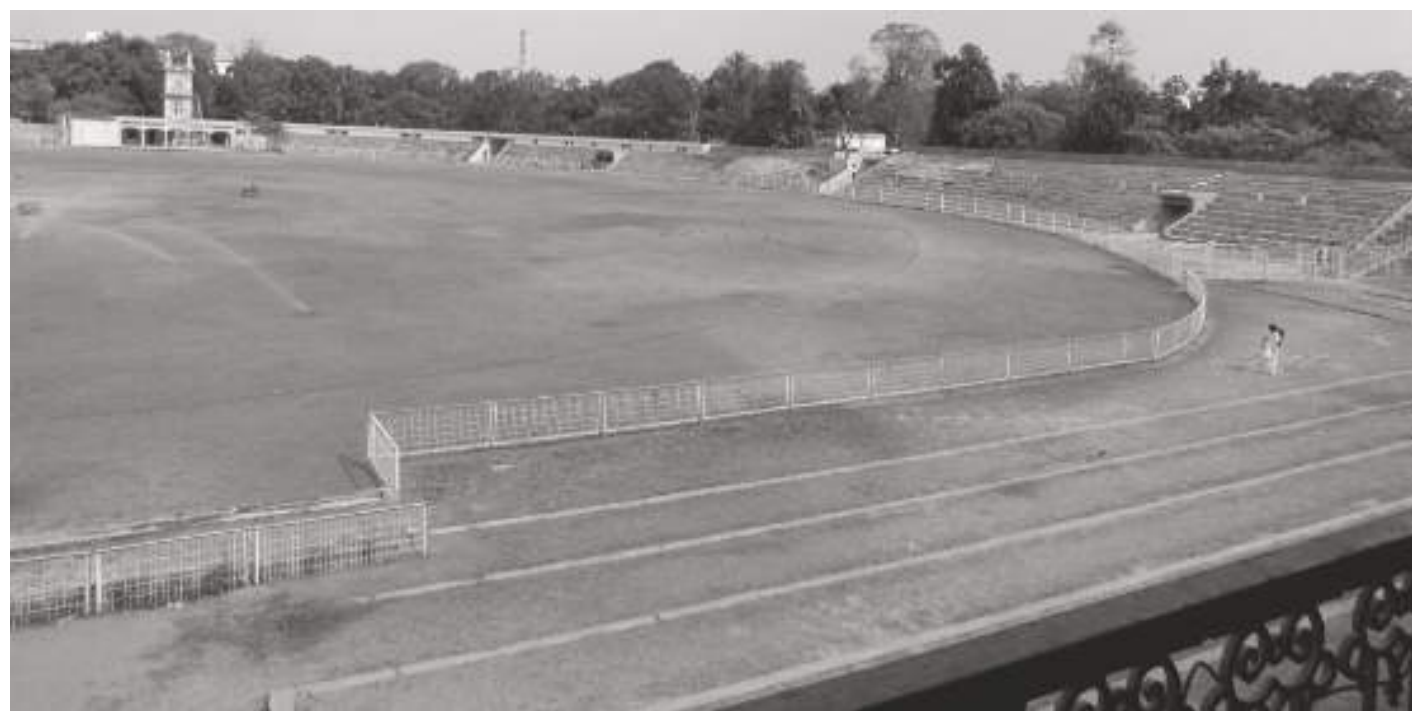

Figure 26. View of stadium from club building (Source: Clicked by Author).

\subsubsection{Structural and constructional elements}

Building has a flat roof, load is distributed through the ribs vaults. All walls are 1.6' thick which is transferring the load (Fig. 27)(Fig. 28)(Fig. 29)(Fig. 30).

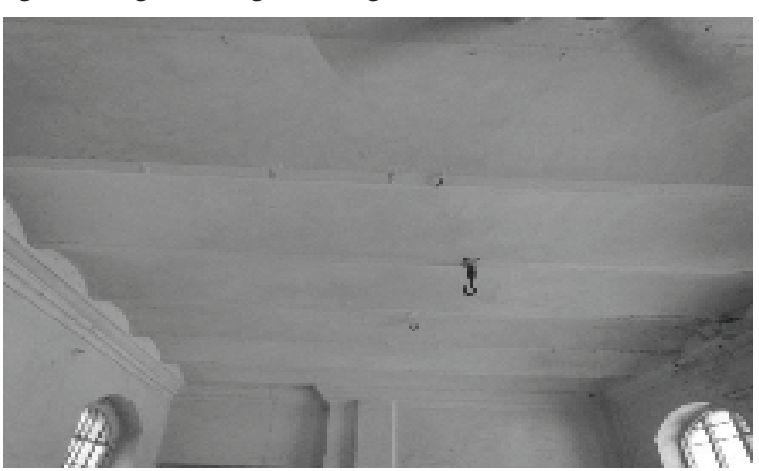

Figure 27. Vaulted ribs roof transferring the load to the huge walls. It's made by iron girders and bricks as a basic construction material (Source: Clicked by Author)..

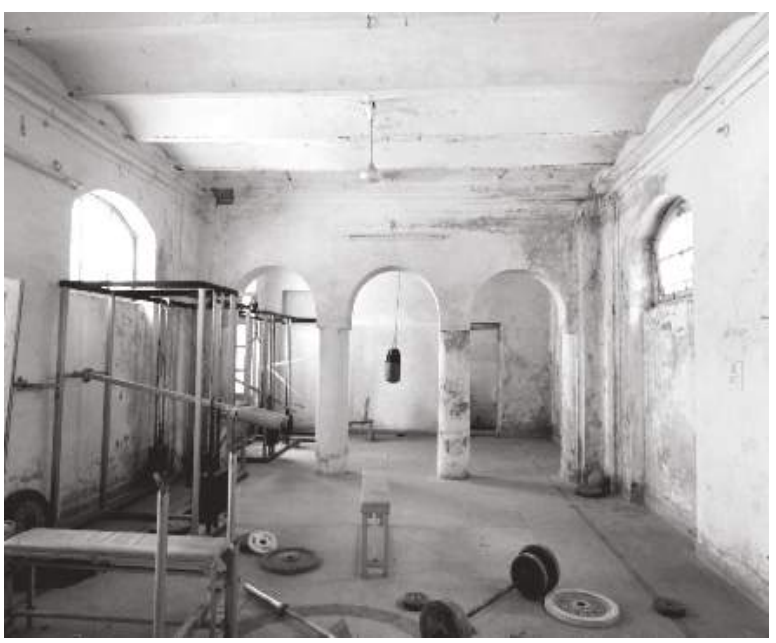

Figure 28. Kota stone as a flooring material, which is laid later on. Huge thick circular columns inside the room to share the load. (Source: Clicked by Author).. 


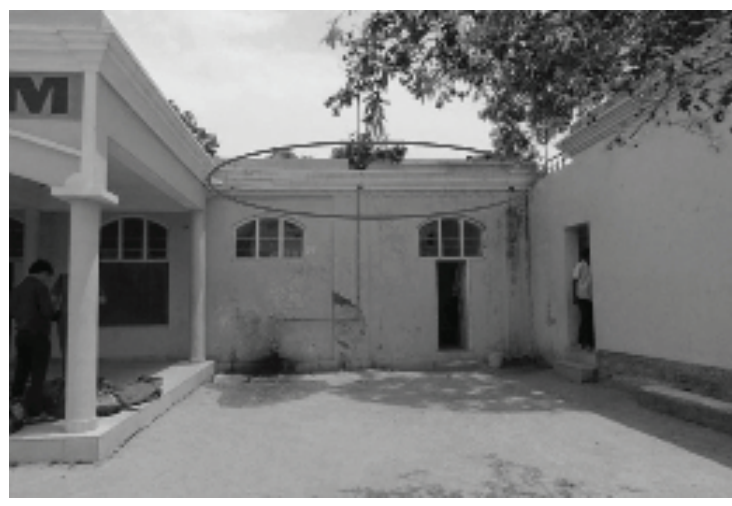

Figure 29. Cornice band is running at the top of the building (Source: Clicked by Author).

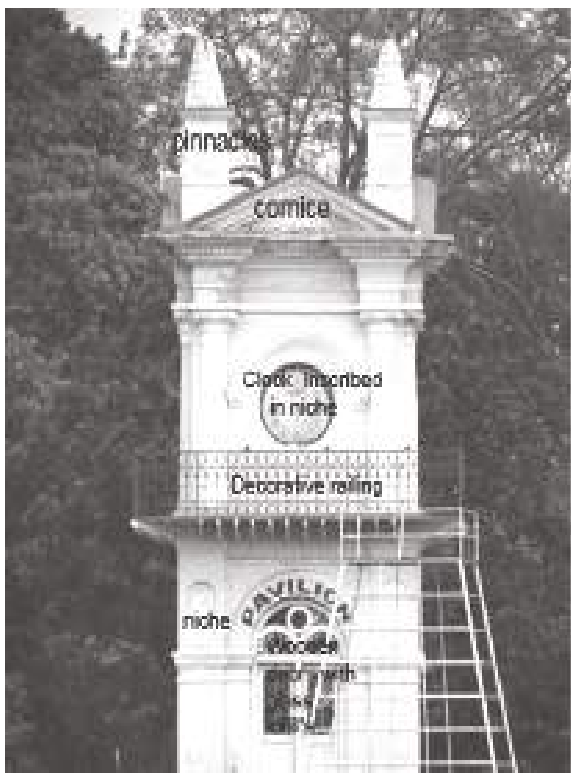

Figure 30. Pavilion Tower (Source: Clicked by Author).

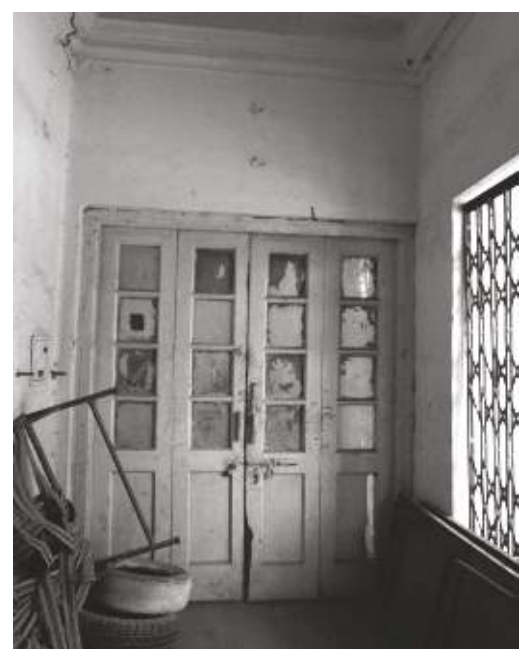

Figure 31. Wooden door, with glass and wooden panel infill (Source: Clicked by Author).

\subsubsection{Architectural elements}

This building also has a colonial architectural style. Linear elements are used in the entire building (Fig. 31)(Fig. 32) (Fig. 33)(Fig. 34).

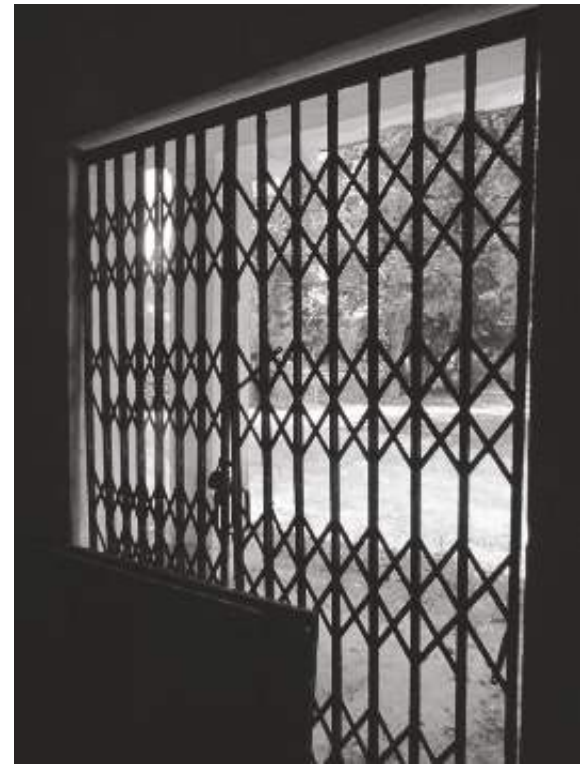

Figure 32. Collapsible door which was earlier act as a main entry to the stadium. (Source: Clicked by Author).

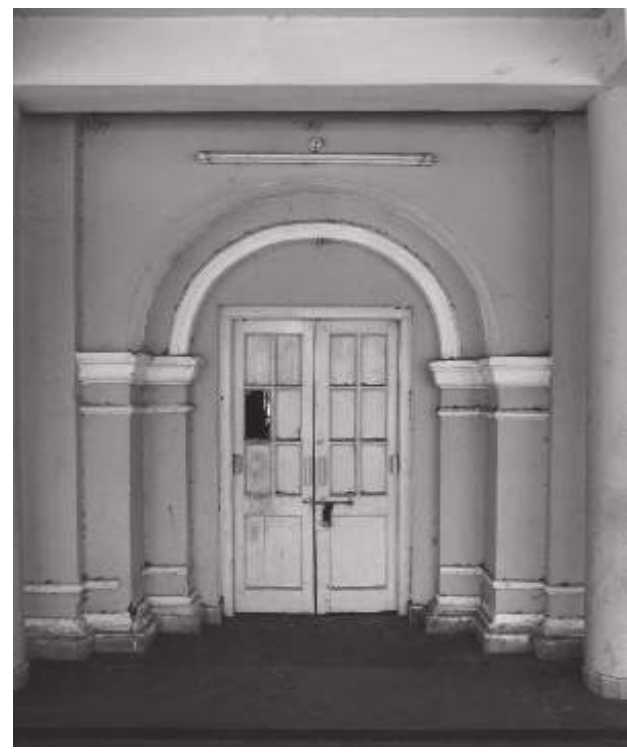

Figure 33. Wooden entrance door, inscribed in double arches which are supported through huge pilasters (Source: Clicked by Author).

\section{Conclusion}

With the advent of British Empire in $18^{\text {th }}$ century, modernization took place in every aspect of Asian countries. 
Dhruve Pandove Stadium is one of the example to show how princely state maharajas adopted British modern life style for the purpose of entertainment and recreation. Once the source of entertainment for maharajas of Patiala from $18^{\text {th }}$ century, Dhruve Pandove stadium is still active today for the same purpose. The planning and construction techniques used in this buildings shows the impact of colonial architectural style.

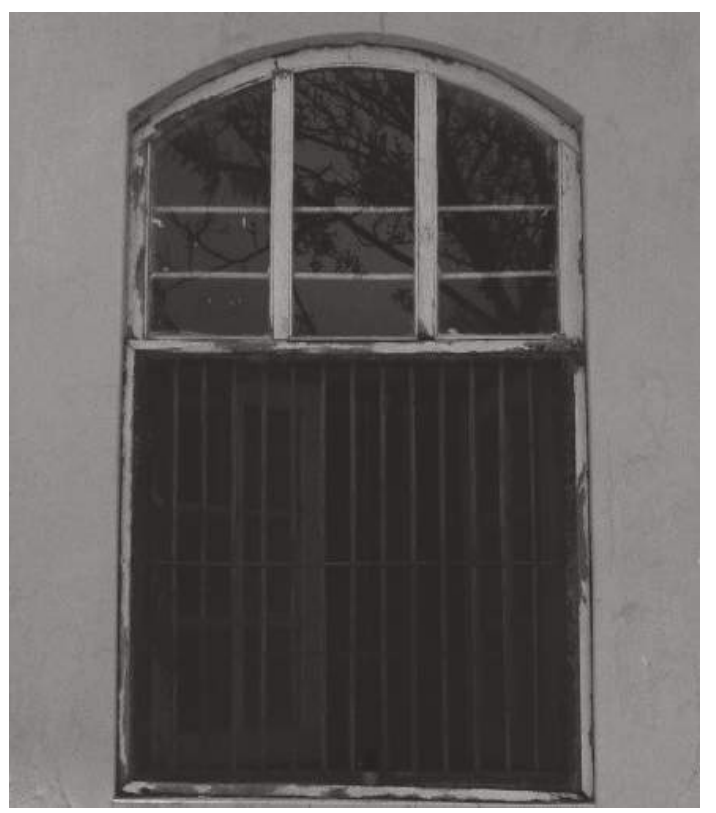

Figure 34. Typical window design (Source: Clicked by Author).

\section{References}

[1] Borsa, G. (2000) The modernization of Asia and the western impact. Journal II Portico, 65, No. 1 [online] 151. Available from: https://www.jstor.org/ stable/24005445?seq=1\#page_scan_tab_contents

[2] Chatterjee, P. (2015) Article; Times May Have Changed But These 10 Colonial Clubs In Kolkata Remain Just As Popular. Available from: http://www. polkacafe.com/colonial-clubs-in-kolkata-1642.html

[3] Chail Cricket Ground (2017) In Wikipedia, The Free Encyclopedia. Available from: https://en.wikipedia. org/wiki/Chail_Cricket_Ground

[4] Eden Gardens (2017) In Wikipedia, The Free Encyclopedia. Available from: https://en.wikipedia. org/wiki/Eden_Gardens.

[5] Ghouse A.N. (1954) ed., The Board of Control for Cricket in India, 1928-53[online pdf available] 1-54. Available from: http://shodhganga.inflibnet.ac.in/ bitstream/10603/117559/7/07_chapter\%201.pdf
[6] Historical studies. Popular recreation in pre-industrial Britain [Online complete pdf] 9-11. Available from https://www.pearsonschoolsandfecolleges. co.uk/FEAndVocational/SportsStudies/ALevel/ OCRALevelPE2008/Samples/A2PEStudentBook SamplePages/PEforOCR(A2)SBCH01.pdf

[7] Indian History, Princely States and Provinces. Article. Available from: http://adaniel.tripod.com/princely.htm.

[8] James, D. (2015) Article. World's highest cricket ground in Himachal Pradesh, and the stadium that will soon be built even higher. Available from: https:// www.sportskeeda.com/cricket/worlds-highest cricketground-stadium-built-even-higher.

[9] Khare-ghose, A. (2016) Article. Memorabilia of India's First Cricket Superstar, Ranjitsinhji. Available from: http://in.blouinartinfo.com/news/story/1451240/ memorabilia-of-indias-first-cricket-superstarranjitsinhji-at

[10] Majumdar, B. (2008) Cricket in Colonial India[online pdf available] 3-5, Available from: https://books. google.co.in/books?id=FcyMAQAAQBAJ\&pg=PA $4 \& \mathrm{lpg}=\mathrm{PA} 4 \& \mathrm{dq}=$ cricket + and + maharajas + of + patial a\&source $=$ bl\&ots $=$ W2 2 Y Yc3B $2 \&$ sig $=8$ n $4 \mathrm{zAXu} 160$ 4Bvl8WSE9DD2EszdY\&hl=en\&sa $=X \& v e d=0 a h U$ KEwjFvMCSmvDVAhUDMo8KHVhWCBU4Ch DoAQgpMAE\# $\mathrm{v}=$ onepage $\& \mathrm{q}=$ cricket $\% 20$ and $\% 20$ maharajas\%20of\%20patiala\&f=false.

[11] National Institute of Open Schooling (2008), Module I India and the World through the Ages. Impact of British rule on India: Economic, Social and Cultural (1757-1857) [online complete pdf] 104-123. Available from : http://www.nios.ac.in/ media/documents/secsocscicour/english/lesson-05.pdf

[12] Ritchie, A. (2004) Ethnicity, Sport, Identity: Struggles for Status. [ online complete pdf] 141 Availablefrom: https://books.google.co.in/books?id=tUaRAgAAQBA $\mathrm{J} \& \mathrm{pg}=\mathrm{PA} 141 \& \mathrm{lpg}=\mathrm{PA} 141 \& \mathrm{dq}=$ sports + and + maharaj as + of + patiala\&source $=$ bl\&ots=ed6idYZe29\&sig=Ox YPfeXA1sh2uDwUVscahZn9fik\&hl=en\&sa=X\&ved $=0 \mathrm{ahUKEwjy} 19 \mathrm{Ty} 5 \mathrm{OzVAhUTS} 48 \mathrm{KHVhjDww4C}$

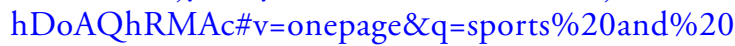
maharajas $\% 20 \mathrm{of} \% 20$ patiala $\& \mathrm{f}=$ false.

[13] Sarkar, A. (2016) Article. Once Upon A Time: Bombay Gymkhana was first club to bring multiple sports together. Available from: http://indianexpress.com/ article/cities/mumbai/once-upon-a-time-bombaygymkhana-was-first-club-to-bring-multiple-sportstogether-2988064/

[14] Sharma, P. (2011) Article. Patiala royals endorsed cricket in India. Available from: http://timesofindia. 
indiatimes.com/india/Patiala-royals-endorsedcricketinIndia/articleshow/7525504.cms.

[15] The Cricket Club of India. History. Available from: http://www.thecricketclubofindia.com/history.
[16] Visual Documentation of socio-cultural ethos spanning over time. Available from: https://puronokolkata. $\mathrm{com} /$ category/gallery/establishments/socio-culturalinstitutions/sports-recreation/ 